\title{
REVIEWS
}

\section{The Nanopharmacology and Nanotoxicology of Nanomaterials: New Opportunities and Challenges}

${ }^{1}$ School of Pharmacy and Pharmaceutical Sciences and Trinity Biomedical Sciences Institute, The University of Dublin, Trinity College, Dublin, Ireland

${ }^{2}$ Eleonora Reicher National Institute of Geriatrics, Rheumatology and Rehabilitation, Warszawa, Poland

${ }^{3}$ Kardio-Med Silesia, Zabrze, Poland

A - research concept and design; $\mathbf{B}$ - collection and/or assembly of data; $\mathbf{C}$ - data analysis and interpretation;

$\mathbf{D}$ - writing the article; $\mathbf{E}$ - critical revision of the article; $\mathbf{F}$ - final approval of article

\begin{abstract}
The very dynamic growth of nanotechnology, nanomaterials (sized 1-100 nm) and their medical applications over the past 10 years has promised to add a new impetus to the diagnostics and therapeutics of a wide range of human pathologies, including cancer, cardiovascular diseases and diseases of the central nervous system. This growth in nanomedicine also fuels advances in bioengineering, regenerative medicine and the development of medical devices. However, as with all new pharmaceuticals and medical devices, new opportunities are inherently accompanied by new challenges due to the ability of nanomaterials to interact with the body on the cellular, subcellular and molecular levels. This article reviews some of the most compelling problems related to the nanopharmacology and nanotoxicology of nanomaterials. The overview focuses on opportunities emerging from the development of multifunctional nanomaterials and nanotheranostics for the diagnostics and therapy of both major and rare diseases. Challenges related to the hemocompatibility of nanomaterials are also discussed (Adv Clin Exp Med 2016, $25,1,151-162)$.
\end{abstract}

Key words: nanotechnology, nanomedicine, pharmacology, toxicology.

The 2011 European Commission recommendation defines "nanomaterial" as: "a natural, incidental or manufactured material containing particles, in an unbound state or as an aggregate or as an agglomerate and where, for $50 \%$ or more of the particles in the number size distribution, one or more external dimensions is in the size range 1-100 $\mathrm{nm}$. In specific cases and where warranted by concerns for the environment, health, safety or competitiveness the number size distribution threshold of $50 \%$ may be replaced by a threshold between 1 and $50 \%$. [...]" [1].

The world market for nanomaterials has been growing extremely fast. It is estimated that $11 \mathrm{mil}-$ lion ton of nanomaterials are produced annually, with a market value of 20 billion euros; in 2015 products underpinned by nanotechnology were valued at 2 trillion euros [1]. It is important to note that nanotechnology is viewed by the European Union (EU) as one of the major technological drivers of innovation and has been identified as a key enabling technology (KET) for the EU [2].

Medicine is expected to be one of the major beneficiaries of the growth of nanotechnology. This is reflected by a great interest on the part of the scientific community in medical applications of nanotechnology. At the time when this article was written (October 2015) a search for "nanomedicine" and "nanoparticles" in Pubmed listed 11,114 and 109,996 publications, respectively. A significant portion of these contributions have been published in newer journals entirely focusing on nanotechnology and nanomedicine, including Nature Nanotechology, Nanomedicine (London), Nanomedicine NBM or The International Journal of Nanomedicine, to name only a few.

In 2007 in a highly accessed and widely cited article published in The British Journal of Pharmacology the authors alerted the pharmaceutical community to the new and growing field of 
nanotechnology research relevant to pharmacology and toxicology [3]. Over the past eight years the field has grown very rapidly, resulting in the publication of a great number of original and review articles. Table 1 presents selected published reviews covering a cross section of topics from nanomedicine, nanopharmacology and nanotoxicology.

Table 1. Selected nanomedical reviews

\begin{tabular}{|c|c|}
\hline Reference $[\#]$ & Topic \\
\hline Ali-Boucetta and Kostarelos 2013 [53] & Toxicokinetics of carbon nanotubes \\
\hline Allen and Cullis 2013 [54] & State-of-the-art of liposomal drug delivery systems \\
\hline Alvarim et al. 2014 [55] & Therapy using SPION-labelled stem cells \\
\hline Andersen et al. 2012 [56] & Adverse immune effects of carbon nanotubes \\
\hline Arora et al. 2012 [57] & Using in vitro methods in nanotoxicology \\
\hline Bao et al. 2013 [58] & Multifunctional NPs for drug delivery and imaging \\
\hline Bartenck et al. 2014 [59] & Nanomedicine to treat liver diseases \\
\hline Benetti et al. 2014 [60] & Nanometallomics in nanotoxicology \\
\hline BeruBe et al. 2007 [61] & Pulmonary toxicity of combustion-derived nanoparticles \\
\hline Billi et al. $2010[62]$ & Nanotoxicology of metallic nanoparticles in total joint arthroplasty \\
\hline Bussy et al. 2013 [63] & Interactions of carbon nanotubes with blood \\
\hline Caputo et al. 2014 [64] & Engineered nanomaterials as antioxidants \\
\hline Carraciolo 2015 [65] & Liposome-protein corona in targeted drug delivery \\
\hline Chaudhury et al. 2014 [66] & Regenerative nanomedicine: current state and future perspectives \\
\hline Chen and Liu 2015 [67] & Pharmaceutics of nanofibers and their role in delivery of antimicrobials \\
\hline Chen et al. 2014 [68] & $\begin{array}{l}\text { State-of-the-art and perspectives of therapeutic and diagnostic use of ther- } \\
\text { anostic nanoparticles }\end{array}$ \\
\hline Chen et al. 2013 [69] & Use of advanced nuclear analytical techniques in nanotoxicology \\
\hline Cheng et al. 2015 [70] & Therapeutic potential of polymeric nanoparticles \\
\hline Cockburn et al. 2012 [27] & Safety of nanomaterials used in food industry: guidelines \\
\hline Conde and Artzi 2015 [71] & Gold nanobeacons in smart nanotheranostics \\
\hline Costa et al. 2015 [72] & $\begin{array}{l}\text { Layer-by-layer technology for preparation of nanoreservoirs for controlled } \\
\text { drug release }\end{array}$ \\
\hline Das Neves et al. 2015 [73] & Nanocarriers for vaginal drug delivery \\
\hline De Vries et al. 2015 [74] & Delivery of antimicrobial peptides using nanocarriers \\
\hline Del Pino 2014 [43] & Interactions of medically-relevant nanoparticles with electromagnetic fields \\
\hline Deshayes et al. 2014 [75] & Cage nanoparticles for drug delivery \\
\hline Doktorovova et al. 2014 [76] & Nanotoxicology of solid lipid nanoparticles \\
\hline Donaldson et al. 2010 [77] & Genotoxicity of nanoparticles \\
\hline Donaldson et al. 2013 [78] & Adverse effects of nanoparticles in the cardiovascular system \\
\hline Estelrich et al. 2015 [79] & Nanoparticles for magnetic resonance imaging \\
\hline Feng et al. 2015 [80] & Toxicity of dental nanomaterials \\
\hline Fernandes et al. 2015 [81] & Targeting digestive cancers using nanotreatments \\
\hline Franci et al. 2015 [82] & Silver nanoparticles as antibacterials \\
\hline
\end{tabular}


Table 1. Selected nanomedical reviews - cont.

\begin{tabular}{|c|c|}
\hline Reference $[\#]$ & Topic \\
\hline Frohlich 2015 [83] & Nanoparticle immunotoxicity in vivo \\
\hline Fubini et al. 2010 [84] & Nanotoxicity in relation to physico-chemical features of nanoparticles \\
\hline Gainza et al. 2015 [85] & Nanocarriers in wound healing and skin regeneration \\
\hline Gendelman et al. 2015 [86] & $\begin{array}{l}\text { Nanotreatment for degenerative, inflammatory and infectious diseases of } \\
\text { the nervous system }\end{array}$ \\
\hline Gharagozloo et al. 2015 [87] & Nanomedical treatment of autoimmune diseases \\
\hline Gregori et al. 2015 [88] & Nanomedical treatment of Alzheimer's disease \\
\hline Grieger et al. 2012 [50] & Environmental risk of nanomaterials \\
\hline Guo and Huang 2014 [89] & Enhancing solubility of anticancer drugs \\
\hline Gusic et al. 2014 [90] & Nanoscaffolding in bone regeneration \\
\hline Holden et al. 2014 [91] & Bacteria for assessing environmental hazards and fates of nanomaterials \\
\hline Hristozov et al. 2014 [92] & Hazard screening of engineered nanomaterials \\
\hline Hubbs et al. 2014 [93] & Augmented microscopy assessment in nanotoxicology \\
\hline $\begin{array}{l}\text { Ilinskaya and Dobrovolskaia } 2013 \text { (part II) } \\
\text { [94] }\end{array}$ & Undesirable action of nanoparticles on blood clotting \\
\hline $\begin{array}{l}\text { Ilinskaya and Dobrovolskaia } 2013 \text { (part I) } \\
\text { [95] }\end{array}$ & Desirable action of nanoparticles on blood clotting \\
\hline Jo et al. 2015 [96] & $\begin{array}{l}\text { Nanoparticles in treatment of retinal diseases: nanotherapeutic agent char- } \\
\text { acteristcs }\end{array}$ \\
\hline Johnston et al. 2013 [52] & Risk of engineered nanomaterials \\
\hline Kandi and Kandi 2015 [97] & Overcoming anti-bacterial resistance with nanoparticles \\
\hline Kermanizadeh et al. 2015 [98] & Role of redox mechanisms in nanomaterial toxicity \\
\hline Kim et al. 2015 [99] & Nanoparticles for siRNA delivery in cancer therapy \\
\hline Kodiha et al. 2015 [100] & Gold nanoparticles for cancer therapy \\
\hline Lakkakula et al. 2014 [101] & Cyclodextrin nanoparticles for drug delivery \\
\hline Landriscina et al. 2015 [102] & Biodegradable chitosan nanoparticles in drug delivery systems \\
\hline Larson et al. 2014 [103] & Reproductive toxicity of nanomaterials \\
\hline Laurent et al. 2014 [104] & Superparamagnetic iron oxide nanoparticles in therapy \\
\hline Li et al. 2015 [105] & Photodynamic therapy using graphene-based nanoplatforms \\
\hline Li YF et al. 2015 [106] & $\begin{array}{l}\text { Use of advanced light beams generated by synchrotron for nanotechnology } \\
\text { and nanotoxicology }\end{array}$ \\
\hline Lukowiak et al. 2015 [107] & Unimolecular micelles for drug delivery \\
\hline Lux et al. 2015 [108] & Gadolinium-based nanotheranostics \\
\hline Madl et al. 2015 [109] & Nanotoxicology of hip implants part I \\
\hline Madl, Kovochich et al. 2015 [110] & Nanotoxicology of hip implants part II \\
\hline Mottaghitalab et al. 2015 [111] & Silk fibroin nanoparticle in drug delivery systems \\
\hline Mulder et al. 2014 [112] & Diagnosis and treatment of atherosclerosis using nanomedical tools \\
\hline Muller et al. 2011 [113] & Nanotoxicology of nanocrystals \\
\hline Murugan et al. 2015 [114] & Mechanisms of cellular trafficking of nanostructures \\
\hline
\end{tabular}


Table 1. Selected nanomedical reviews - cont.

\begin{tabular}{|c|c|}
\hline Reference $[\#]$ & Topic \\
\hline Nel 2013 [115] & Safety assessment of nanomaterials using alternative test strategies \\
\hline Nel et al. 2013 [116] & $\begin{array}{l}\text { Predictive toxicological approach and high-throughput screening in nano- } \\
\text { toxicology }\end{array}$ \\
\hline Nielsen et al. 2014 [117] & Nanomedicine in the treatment of inflammatory bowel disease \\
\hline Nunez-Anita et al. 2014 [118] & Toxicity of antimicrobial nanoparticles used in prosthetic devices \\
\hline Osmond et al. 2010 [119] & Nanotoxicity of modern sunscreens \\
\hline Palekar et al. 2015 [19] & $\begin{array}{l}\text { Molecular imaging of atherosclerosis using nanoparticle-based fluorinated } \\
\text { magnetic resonance contrast agents }\end{array}$ \\
\hline Panzarini and Dini 2014 [120] & Overcoming multidrug cancer cell resistance using nanomaterials \\
\hline Paul 2015 [121] & Myocardial therapy using nanocomposite hydrogels \\
\hline Polak and Shefi 2015 [122] & Neuronal regeneration using nanoparticles \\
\hline Sadikot 2014 [123] & Nanomaterials in critical care medicine \\
\hline Schrofel et al. 2014 [124] & Biomedical applications of metallic nanoparticles \\
\hline Sehedic et al. 2015 [125] & Overcoming radioresistance of glioblastoma using nanomaterials \\
\hline Shvedova and Kagan 2010 [126] & Pulmonary toxicity of single-wall carbon nanotubes \\
\hline Sosnik and Carcaboso 2014 [127] & Nanomedicine in paediatrics \\
\hline Sriraman et al. 2014 [128] & Brain tumour targeting using multifunctional nanoparticles \\
\hline Tan et al. 2011 [129] & Quantum dots and carbon nanotubes in oncology \\
\hline Tomaszewski et al. 2015 [38] & $\begin{array}{l}\text { Nanopharmacology and nanotoxicology in platelet-vascular wall interac- } \\
\text { tions }\end{array}$ \\
\hline Torchilin 2014 [130] & Multifunctional and stimuli-sensitive drug delivery systems \\
\hline Tseng and Liu 2015 [131] & Delivery of analgesics using nanofibers \\
\hline Veiseh et al. 2015 [132] & Nanodrug discovery and the treatment of diabetes mellitus \\
\hline Vellayappan et al. 2015 [133] & Nanocomposites for grafts and stents \\
\hline Vinogradov et al. 2014 [134] & Targeting macrophages associated with tumour using nanoparticles \\
\hline Walmsley et al. 2014 [135] & Nanotechnology in bone tissue engineering \\
\hline Wang et al. 2015 [136] & Boron-functionalized nanocarriers for cancer treatment \\
\hline Weissig et al. 2014 [6] & Approved and commercially available nanopharmaceuticals \\
\hline $\begin{array}{l}\text { Weissig and Guzman-Villanueva } \\
2014 \text { [137] }\end{array}$ & Approved and commercially available nanopharmaceuticals \\
\hline White-Schenk et al. 2015 [138] & Nanopharmaceuticals in spinal cord injury \\
\hline Winkler et al. 2014 [139] & Structure-activity relationship (SAR) approach in nanotoxicology \\
\hline Zhao et al. 2014 [140] & Nanotechnology in glycopeptide detection and glycoproteomics \\
\hline Zhen et al. 2014 [141] & Ferritins as multifunctional nanoplatforms \\
\hline
\end{tabular}

As with all medical research and development $(R \& D)$, diagnostic and therapeutic options in nanomedicine, in addition to the new opportunities, involve certain risks, and the risk/benefit balance is likely to influence the fate of nanomedical R\&D.
This overview focuses on opportunities emerging from the development of multifunctional nanomaterials for diagnostics and therapeutics. Challenges related to the biocompatibility of newly developed nanomaterials are also discussed, highlighting blood-nanoparticle interactions. 


\section{Opportunities}

Most nanodrug research to date has been based on the principle of using nanoparticles as drug delivery platforms. In fact, the first nanodrug approved by the US Food and Drug Administration (FDA) for use in men was Doxil [4], in which liposomal encapsulation of doxorubicin was used to increase the drug/carrier ratio and to decrease the cardiac toxicity and adverse effects associated with the use of this anticancer drug [5].

To the time of writing, more than 40 nanopharmaceuticals have been approved by regulatory authorities, including liposomes, non-liposomal lipid formulations, PEGylated proteins, peptides, aptamers, nanocrystals, polymer-based nanoformulations, protein-drug conjugates, surfactantbased nanoformulations, metal-based nanoformulations and virosomes [6].

The field of anticancer drug delivery has been a major beneficiary of nanomedical R\&D, with a number of FDA-approved anticancer formulations, such as nanosized antibody-drug conjugates brentuximab and trastuzumab [7], liposome-containing daunorubicine [8] and vincristine [9], as well as paclitaxel formulated using a nanosized albumin carrier [10]. As with Doxil, the use of nanoplatforms is likely to increase the selectivity and efficacy of these anticancer drugs while reducing the adverse effects.

A number of nanotherapeutic products are commercially available in the EU, including nanocrystals (sirolimus, fenofibrate and aprepitant), nanoemulsions (cyclosporine and ritonavir) polymeric drugs (sevelamer) and liposomes (amphotericin B, cytarabine, doxorubicin and daunorubicin) [11].

Recently, yet another dimension of nanoparticle drug delivery systems has been gaining increasing momentum in nanomedical R\&D: nanotheranostics, based on the use of multifunctional nanoparticles that integrate diagnostic and therapeutic functions in one system [12]. For cancer treatment, nanotheranostic platforms can provide advanced diagnostics, hyperthermia treatment and targeted delivery of anticancer drugs [13]; superparamagnetic iron oxide nanoparticles (SPIONs) are an example of such platforms [14, 15]. SPIONs have also been developed as a part of the MULTIFUN EU consortium (http://www.multifun-project.eu/) [16] and offer distinct advantages over other drug delivery platforms used with anticancer medications: a) the pharmacokinetics of SPIONs are easily determined using non-invasive imaging techniques such as nuclear magnetic resonance (NMR); b) SPIONs can easily be guided to cancer tissues using the electromagnetic field (EM);
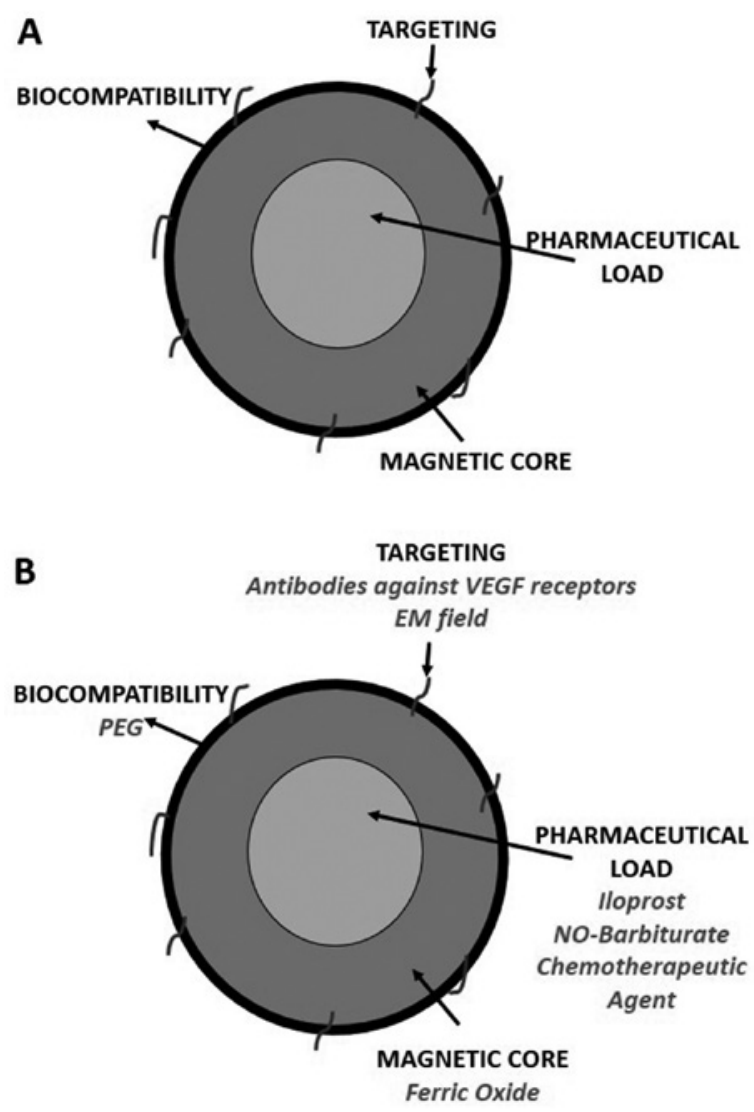

Fig. 1. A) The general design and functionalization of multifunctional magnetic nanoparticles: a magnetic core capable of scattering or absorption of an interacting electromagnetic field, allowing diagnostics and treatment; a pharmaceutical load for selective delivery of therapeutics; antibodies that target specific cellular markers, and biocompatibility with polyethylene glycol (PEG), allowing a longer half-life of nanoparticles in the bloodstream $[13,43,54]$

B) A proposed design for multifunctional ferromagnetic nanoparticles for the treatment of Kasabach-Merrit disease: a ferromagnetic core using ferric oxide; a pharmaceutical load with a chemotherapeutic agent [25] a nitric oxide (NO)/barbiturate hybrid, a strong inhibitor of cancer-cell proliferation and secretion [142], and iloprost, an analog of prostacyclin, a potent inhibitor of platelet aggregation that synergizes with NO [143]; targeting hemangioma cells using antibodies against vascular endothelial growth factor receptors [144] and an EM field; and a coating providing biocompatibility with PEG

c) SPIONs can selectively generate energy to destroy cancer cells; and d) when functionalized with antibodies against cancer biomarkers, SPIONs can selectively deliver a "cocktail" of therapeutic pharmaceuticals (Fig. 1a).

Nanotheranostics can be also used for the management of atherosclerosis and its cardiovascular and cerebrovascular manifestations [17-19]. As with cancer, it is expected that multimodal nanoparticles will allow for non-invasive detection, long-term monitoring (for example using 
gadolinium-based contrasts and dynamic contrast enhanced magnetic resonance imaging) and treatment of atherosclerotic plaques $[20,21]$. The European Union actively supports projects related to the use of nanomedicine to combat atherosclerosis. One of the ongoing projects is the NanoAthero consortium (http://www.nanoathero.eu/), which aims at targeted imaging and treatment of advanced atherothrombotic disease in humans.

In addition to major diseases such as cancer and cardiovascular diseases, nanotheranostics can also be applied to the diagnostics and treatment of rare diseases. The Kasabach-Merritt syndrome [22], also known as the Kasabach-Merritt phenomenon (KMP) or thrombocytopenia with a vascular lesion, is a rare condition [23] that complicates the course of two rare vascular tumors: kaposiform hemangioendothelioma (KHE) and tufted angioma (approximately $1 \%$ of all hemangiomas), believed to be on the spectrum of the same disease [24]. Albeit a rare disease, KMP is a lifethreatening one leading to profound thrombocytopenia $(3,000-60,000 / \mu \mathrm{L})$, hypofibrinogenemia, bleeding and sometimes to disseminated intravascular coagulation. The exact pathogenesis of KMP is uncertain; however, platelets being trapped in a hemangioma with an abnormal proliferating endothelium is the most likely cause [25]. Despite various treatment modalities including surgery, supportive and systemic pharmacological treatment, the prognosis of KMP remains uncertain [26] and there is therefore an urgent need to develop more effective treatments. The use of multifunctional ferromagnetic nanoparticles may represent a theranostic option (Fig. 1 b).

\section{Challenges}

Nanomaterials can enter the body via a number of portals, such as the skin, respiratory tract or gastrointestinal tract, or through parenteral administration $[27,28]$. The translocation of nanoparticles to the bloodstream allows interactions between nanomaterials, plasma and blood elements to take place. Nanoparticles' contact with plasma proteins leads to the formation of a "protein corona" [29], which may modify the biological and pharmacological properties of the nanoparticles [30].

Over the past 10 years the authors have pioneered and studied the effects of nanoparticles on vascular hemostasis and blood platelet function, as platelet-nanoparticle interactions are likely to play a major role in the hemocompatibility of nanomaterials. These studies have shown that soluble and surface-bound carbon nanoparticles have the ability to stimulate platelet aggregation and to increase thrombosis in vitro and in vivo [31,32]. Other inorganic nanomaterials, such as silica nanoparticles [33], gold nanoparticles [34] and quantum dots [35], may also stimulate platelet activation. Interestingly, organic nanoparticles appear to be more platelet-compatible than inorganic nanomaterials [36], and this compatibility can also be increased by nanoparticle surface functionalization [34]. The molecular mechanisms involved in the interactions of platelets with nanomaterials are multifactorial, but they may be triggered by the generation of reactive oxygen and nitrogen species such as peroxynitrite $[33,37]$, and depend on the modification of receptors, transport systems and intraplatelet transduction mechanisms [38].

The authors have also designed unique test systems for studying the effects of nanoparticles on platelets. The use of a quartz crystal microbalance facilitates highly sensitive measurement of platelet microaggregate formation during interactions among nanoparticles, platelets and other cells under flow conditions [32, 34, 35, 38-42].

An understanding of the subcellular mechanisms involved in nanomaterial hemocompatibility, as well as the availability of sensitive methods for studying such interactions, will be of great assistance when developing diagnostic and therapeutic options using multifunctional nanomaterials. Multifunctional nanoparticles including materials with ferromagnetic cores rely on their ability to interact efficiently with EM fields to produce a response through the scattering or absorption of the interacting field [43]. EM-mediated responses may be used for selective detecting, targeting, monitoring and treating a wide cross section of human diseases. However, the impact of an EM field on interactions between mutlifunctional nanoparticles, cells and subcellular structures needs to be carefully evaluated to determine the risk/benefit ratio of such pharmaceuticals.

It is also important to point out that there are compelling differences between various medically relevant nanomaterials. Therefore, the $\mathrm{R} \& \mathrm{D}$ as well as the registration of novel nanodiagnostic/nanotherapeutic agents with the FDA and European Medicines Agency is likely to proceed on a case-to-case basis. The pharmaceutical industry may, however, be vitally interested in nanotherapeutic ventures. Indeed, over the past few years large, research-intensive pharmaceutical companies have had to deal with the effects of the socalled "patent cliff". The patent cliff results from the expiry of patents for major pharmaceutical blockbusters, which leads to decreased revenues for the producers of the patented product. Therefore, uniquely formulated nanodrugs based on existing compounds may be one way to go for the 
research-intensive pharmaceutical industry to deal with patenting problems [44].

Finally, it is worth commenting on risk and safety assessment associated with the use of nanopharmaceuticals. As indicated in the "Opportunities" section above, both the FDA and the EU have already set up robust schemes for the approval and legislation of new nanopharmaceuticals; these schemes appear to be working well, and provide comprehensive pharmacological/ /toxicological profiles of novel nanopharmaceuticals. A challenge that requires very careful consideration is the environmental presence and persistence of engineered nanoparticles. It is likely that organic, biodegradable nanoparticles will be of lesser concern, as they will be degraded by metabolic pathways [27]. In contrast, inorganic, non-biodegradable nanoparticles, including multifunctional magnetic nanoparticles, may persist for considerable periods and result in prolonged exposure of humans, animals and the environment with still-to-be-determined consequences. This could potentially add to the pool of engineered nanomaterials present in the environment, which is continually delivered by nanoproducts produced by the food, agriculture and cosmetics industries [27, 45-47]. The outcome of biological interactions between nanomaterials and xenobiotics present in the environment may also be of concern $[48,49]$. Therefore, serious assessment of the environmental risks associated with the growing presence of nanotechnology products in the environment most definitely needs to be carefully considered [50-52].

\section{References}

[1] European Commission: Second regulatory review on nanomaterials 2012.

[2] Savolainen K, Backman U, Brouwer D, Fadel B, Fernandes T, Kuhlbusch T, Landsiedel R, Lynch I, Pylkkanen L, Cluster N: Nanosafety in Europe 2015-2025: Towards Safe and Sustainable Nanomaterials and Nanotechnology Innovations. Finnish Institute of Occupational Health 2013.

[3] Medina C, Santos-Martinez M, Radomski A, Corrigan O, Radomski M: Nanoparticles: pharmacological and toxicological significance. Br J Pharmacol 2007, 150, 552-558.

[4] Barenholz Y: Doxil(R) - the first FDA-approved nano-drug: lessons learned. J Control Release 2012, 160, 117-134.

[5] Dawidczyk CM, Kim C, Park JH, Russell LM, Lee KH, Pomper MG, Searson PC: State-of-the-art in design rules for drug delivery platforms: lessons learned from FDA-approved nanomedicines. J Control Release 2014, 187, $133-144$.

[6] Weissig, V, Pettinger, TK, Murdock, N: Nanopharmaceuticals (part 1): products on the market. Int J Nanomedicine 2014, 9, 4357-4373.

[7] Lambert JM: Drug-conjugated antibodies for the treatment of cancer. Br J Clin Pharmacol 2013, 76, $248-262$.

[8] Fassas A and Anagnostopoulos A: The use of liposomal daunorubicin (DaunoXome) in acute myeloid leukemia. Leuk Lymphoma 2005, 46, 795-802.

[9] Silverman JA and Deitcher SR: Marqibo(R) (vincristine sulfate liposome injection) improves the pharmacokinetics and pharmacodynamics of vincristine. Cancer Chemother Pharmacol 2013, 71, 555-564.

[10] Kundranda MN and Niu J: Albumin-bound paclitaxel in solid tumors: clinical development and future directions. Drug Des Devel Ther 2015, 9, 3767-3777.

[11] Hafner A, Lovric J, Lakos GP, Pepic I: Nanotherapeutics in the EU: an overview on current state and future directions. Int J Nanomedicine 2014, 9, 1005-1023.

[12] Kim TH, Lee S, Chen X: Nanotheranostics for personalized medicine. Expert Rev Mol Diagn 2013, 13, $257-269$.

[13] Gobbo OL, Sjaastad K, Radomski MW, Volkov Y, Prina-Mello A: Magnetic Nanoparticles in Cancer Theranostics. Theranostics 2015, 5, 1249-1263.

[14] Rosen JE, Chan L, Shieh DB, Gu FX: Iron oxide nanoparticles for targeted cancer imaging and diagnostics. Nanomedicine 2012, 8, 275-290.

[15] Yoffe, S, Leshuk, T, Everett, P, Gu, F: Superparamagnetic Iron Oxide Nanoparticles (SPIONs): Synthesis and Surface Modification Techniques for use with MRI and Other Biomedical Applications. Curr Pharm Des 2013, 19, 493-509.

[16] Gobbo OL, Wetterling F, Vaes P, Teughels S, Markos F, Edge D, Shortt CM, Crosbie-Staunton K, Radomski MW, Volkov Y, Prina-Mello A: Biodistribution and pharmacokinetic studies of SPION using particle electron paramagnetic resonance, MRI and ICP-MS. Nanomedicine (Lond) 2015, 10, 1751-1760.

[17] Zapotoczny S, Szczubialka K, Nowakowska M: Nanoparticles in endothelial theranostics: Pharmacological Reports 2015, 67, 751-755.

[18] Mangge H, Almer G, Stelzer I, Reininghaus E, Prassl R: Laboratory medicine for molecular imaging of atherosclerosis. Clin Chim Acta 2014, 437, 19-24.

[19] Palekar RU, Jallouk AP, Lanza GM, Pan H, Wickline SA: Molecular imaging of atherosclerosis with nanoparticle-based fluorinated MRI contrast agents: Nanomedicine (Lond) 2015, 10, 1817-1832.

[20] Lobatto ME, Calcagno C, Millon A, Senders ML, Fay F, Robson PM, Ramachandran S, Binderup T, Paridaans MP, Sensarn S, Rogalla S, Gordon RE, Cardoso L, Storm G, Metselaar JM, Contag CH, Stroes ES, Fayad ZA, Mulder WJ: Atherosclerotic plaque targeting mechanism of long-circulating nanoparticles established by multimodal imaging. ACS Nano 2015, 9, 1837-1847. 
[21] Palekar RU, Jallouk AP, Goette MJ, Chen J, Myerson JW, Allen JS, Akk A, Yang L, Tu Y, Miller MJ, Pham CT, Wickline SA, Pan H: Quantifying progression and regression of thrombotic risk in experimental atherosclerosis. Faseb J 2015, 29, 3100-3109.

[22] Kasabach, HHM and Merritt, KK: Capillary hemangioma with extensive purpura. Report of a case. Am J Dis Child 1940, 59, 1063-1070.

[23] National Organization for Rare Disorders, NORD. In: http://rarediseases.org/.

[24] Adams DM and Hammill A: Other vascular tumors: Semin Pediatr Surg 2014, 23, 173-177.

[25] Hall GW: Kasabach-Merritt syndrome: pathogenesis and management: Br J Haematol 2001, 112, 851-862.

[26] Colmenero I and Hoeger PH: Vascular tumours in infants. Part II: vascular tumours of intermediate malignancy [corrected] and malignant tumours: Br J Dermatol 2014, 171, 474-484.

[27] Cockburn A, Bradford R, Buck N, Constable A, Edwards G, Haber B, Hepburn P, Howlett J, Kampers F, Klein C, Radomski M, Stamm H, Wijnhoven S, Wildemann T: Approaches to the safety assessment of engineered nanomaterials (ENM) in food. Food Chem Toxicol 2012, 50, 2224-2242.

[28] Medina C, Santos-Martinez MJ, Radomski A, Corrigan OI, Radomski MW: Nanoparticles: pharmacological and toxicological significance. Br J Pharmacol 2007, 150, 552-558.

[29] Lundqvist M, Stigler J, Elia G, Lynch, I, Cedervall T, Dawson KA: Nanoparticle size and surface properties determine the protein corona with possible implications for biological impacts. Proc Natl Acad Sci USA 2008, 105, 14265-14270.

[30] Lesniak A, Salvati, A, Santos-Martinez MJ, Radomski MW, Dawson KA, Aberg C: Nanoparticle adhesion to the cell membrane and its effect on nanoparticle uptake efficiency. J Am Chem Soc 2013, 135, 1438-1444.

[31] Radomski A, Jurasz P, Alonso-Escolano D, Drews M, Morandi M, Malinski T, Radomski MW: Nanoparticle-induced platelet aggregation and vascular thrombosis. Br J Pharmacol 2005, 146, 882-893.

[32] Gaffney AM, Santos-Martinez MJ, Satti A, Major TC, Wynne KJ, Gun'ko YK, Annich GM, Elia G, Radomski MW: Blood biocompatibility of surface-bound multi-walled carbon nanotubes. Nanomedicine 2015, $11,39-46$.

[33] Corbalan JJ, Medina C, Jacoby A, Malinski T, Radomski MW: Amorphous silica nanoparticles aggregate human platelets: potential implications for vascular homeostasis. Int J Nanomedicine 2012, 7, 631-639.

[34] Santos-Martinez MJ, Rahme K, Corbalan JJ, Faulkner C, Holmes JD, Tajber L, Medina C, Radomski MW: Pegylation increases platelet biocompatibility of gold nanoparticles. J Biomed Nanotechnol 2014, 10, 1004-1015.

[35] Samuel SP, Santos-Martinez MJ, Medina C, Jain N, Radomski MW, Prina-Mello A, Volkov Y: CdTe quantum dots induce activation of human platelets: implications for nanoparticle hemocompatibility. Int J Nanomedicine 2015, 2723-2734.

[36] Li X, Radomski A, Corrigan OI, Tajber L, De Sousa Menezes F, Endter S, Medina C, Radomski MW: Platelet compatibility of PLGA, chitosan and PLGA-chitosan nanoparticles. Nanomedicine (Lond) 2009, 4, 735-746.

[37] Corbalan JJ, Medina C, Jacoby A, Malinski T, Radomski MW: Amorphous silica nanoparticles trigger nitric oxide/peroxynitrite imbalance in human endothelial cells: inflammatory and cytotoxic effects. Int J Nanomedicine 2011, 6, 2821-2835.

[38] Tomaszewski KA, Radomski MW, Santos-Martinez MJ: Nanodiagnostics, nanopharmacology and nanotoxicology of platelet-vessel wall interactions. Nanomedicine (Lond) 2015, 10, 1451-1475.

[39] Bazou, D, Santos-Martinez, MJ, Medina, C, Radomski, MW: Elucidation of flow-mediated tumour cell-induced platelet aggregation using an ultrasound standing wave trap. Br J Pharmacol 2011, 162, 1577-1589.

[40] Santos-Martinez MJ, Inkielewicz-Stepniak I, Medina C, Rahme K, D’Arcy DM, Fox D, Holmes JD, Zhang H, Radomski MW: The use of quartz crystal microbalance with dissipation (QCM-D) for studying nanoparticle-induced platelet aggregation. Int J Nanomedicine 2012, 7, 243-255.

[41] Santos-Martinez MJ, Prina-Mello A, Medina C, Radomski MW: Analysis of platelet function: role of microfluidics and nanodevices. Analyst 2011, 136, 5120-5126.

[42] Santos-Martinez MJ, Tomaszewski KA, Medina C, Bazou D, Gilmer JF, Radomski MW: Pharmacological characterization of nanoparticle-induced platelet microaggregation using quartz crystal microbalance with dissipation: comparison with light aggregometry. Int J Nanomedicine 2015, 10, 5107-5119.

[43] Del Pino P: Tailoring the interplay between electromagnetic fields and nanomaterials toward applications in life sciences: a review. J Biomed Opt 2014, 19, 101507-101517.

[44] Hofmann-Amtenbrink M, Hofmann H, Hool A, Roubert F: Nanotechnology in medicine: European research and its implications. Swiss Medical Weekly 2014, 144, w14044.

[45] Chin-Chan M, Navarro-Yepes J, Quintanilla-Vega B: Environmental pollutants as risk factors for neurodegenerative disorders: Alzheimer and Parkinson diseases. Front Cell Neurosci 2015, 9, 124.

[46] Ikuma K, Decho AW, Lau BL: When nanoparticles meet biofilms-interactions guiding the environmental fate and accumulation of nanoparticles. Front Microbiol 2015, 6, 591.

[47] Sanchez-Quiles D and Tovar-Sanchez A: Are sunscreens a new environmental risk associated with coastal tourism? Environ Int 2015, 83, 158-170.

[48] Niska K, Pyszka K, Tukaj C, Wozniak M, Radomski MW, Inkielewicz-Stepniak I: Titanium dioxide nanoparticles enhance production of superoxide anion and alter the antioxidant system in human osteoblast cells. Int J Nanomedicine 2015, 10, 1095-1107.

[49] Niska K, Santos-Martinez MJ, Radomski MW, Inkielewicz-Stepniak I: CuO nanoparticles induce apoptosis by impairing the antioxidant defense and detoxification systems in the mouse hippocampal HT22 cell line: protective effect of crocetin. Toxicol In Vitr 2015, 29, 663-671. 
[50] Grieger KD, Linkov I, Hansen SF, Baun A: Environmental risk analysis for nanomaterials: review and evaluation of frameworks. Nanotoxicology 2012, 6, 196-212.

[51] Holden PA, Nisbet RM, Lenihan HS, Miller RJ, Cherr GN, Schime, JP, Gardea-Torresdey JL: Ecological nanotoxicology: integrating nanomaterial hazard considerations across the subcellular, population, community, and ecosystems levels. Acc Chem Res 2013, 46, 813-822.

[52] Johnston H, Pojana G, Zuin S, Jacobsen NR, Moller P, Loft S, Semmler-Behnke M, McGuiness C, Balharry D, Marcomini A, Wallin H, Kreyling W Donaldson K, Tran L, Stone V: Engineered nanomaterial risk. Lessons learnt from completed nanotoxicology studies: potential solutions to current and future challenges. Crit Rev Toxicol 2013, 43, 1-20.

[53] Ali-Boucetta H and Kostarelos K: Pharmacology of carbon nanotubes: toxicokinetics, excretion and tissue accumulation. Adv Drug Deliv Rev 2013, 65, 2111-2119.

[54] Allen TM and Cullis PR: Liposomal drug delivery systems: from concept to clinical applications. Adv Drug Deliv Rev 2013, 65, 36-48.

[55] Alvarim LT, Nucci LP, Mamani JB, Marti LC, Aguiar MF, Silva HR, Silva GS, Nucci-da-Silva MP, DelBel EA, Gamarra LF: Therapeutics with SPION-labeled stem cells for the main diseases related to brain aging: a systematic review. Int J Nanomedicine 2014, 9, 3749-3770.

[56] Andersen AJ, Wibroe PP, Moghimi SM: Perspectives on carbon nanotube-mediated adverse immune effects. Adv Drug Deliv Rev 2012, 64, 1700-1705.

[57] Arora S, Rajwade JM, Paknikar KM: Nanotoxicology and in vitro studies: the need of the hour. Toxicol Appl Pharmacol 2012. 258, 151-165.

[58] Bao G, Mitragotri S, Tong S: Multifunctional nanoparticles for drug delivery and molecular imaging. Annu Rev Biomed Eng 2013, 15, 253-282.

[59] Bartneck M, Warzecha KT, Tacke F: Therapeutic targeting of liver inflammation and fibrosis by nanomedicine. Hepatobiliary Surg Nutr 2014, 3, 364-376.

[60] Benetti, F Bregoli L, Olivato I, Sabbioni E: Effects of metal(loid)-based nanomaterials on essential element homeostasis: the central role of nanometallomics for nanotoxicology. Metallomics 2014, 6, 729-747.

[61] BeruBe K, Balharry D, Sexton K, Koshy L, Jones T: Combustion-derived nanoparticles: mechanisms of pulmonary toxicity. Clin Exp Pharmacol Physiol 2007, 34, 1044-1050.

[62] Billi F, Campbell P: Nanotoxicology of metal wear particles in total joint arthroplasty: a review of current concepts. J Appl Biomater Biomech 2010, 8, 1-6.

[63] Bussy C, Methven L, Kostarelos K: Hemotoxicity of carbon nanotubes. Adv Drug Deliv Rev 2013, 65, $2127-2134$.

[64] Caputo F, De Nicola M, Ghibelli L: Pharmacological potential of bioactive engineered nanomaterials. Biochem Pharmacol 2014, 92, 112-130.

[65] Caracciolo G: Liposome-protein corona in a physiological environment: challenges and opportunities for targeted delivery of nanomedicines. Nanomedicine 2015, 11, 543-557.

[66] Chaudhury K, Kumar V, Kandasamy J, RoyChoudhury S: Regenerative nanomedicine: current perspectives and future directions. Int J Nanomedicine 2014, 9, 4153-4167.

[67] Chen DW and Liu SJ: Nanofibers used for delivery of antimicrobial agents. Nanomedicine (Lond) 2015, 10, $1959-1971$.

[68] Chen F, Ehlerding EB, Cai W: Theranostic nanoparticles. J Nucl Med 2014, 55, 1919-1922.

[69] Chen C, Li YF, Qu Y, Chai Z, Zhao Y: Advanced nuclear analytical and related techniques for the growing challenges in nanotoxicology. Chem Soc Rev 2013, 42, 8266-8303.

[70] Cheng CJ, Tietjen GT, Saucier-Sawyer JK, Saltzman WM: A holistic approach to targeting disease with polymeric nanoparticles. Nat Rev Drug Discov 2015, 14, 239-247.

[71] Conde J and Artzi N: The next generation of smart gold nanobeacons: nanotheranostics is ready for prime time. Nanomedicine (Lond) 2015, 10, 1535-1538.

[72] Costa RR, Alatorre-Meda M, Mano JF: Drug nano-reservoirs synthesized using layer-by-layer technologies. Biotechnol Adv 2015.

[73] das Neves J, Nunes R, Machado A, Sarmento B: Polymer-based nanocarriers for vaginal drug delivery. Adv Drug Deliv Rev 2014.

[74] de Vries R, Andrade CAS, Bakuzis AF, Mandal SM, Franco OL: Next-generation nanoantibacterial tools developed from peptides. Nanomedicine 2015, 10, 1643-1661.

[75] Deshayes S and Gref R: Synthetic and bioinspired cage nanoparticles for drug delivery. Nanomedicine (Lond) $2014,9,1545-1564$.

[76] Doktorovova S, Souto EB, Silva AM: Nanotoxicology applied to solid lipid nanoparticles and nanostructured lipid carriers - a systematic review of in vitro data. Eur J Pharm Biopharm 2014, 87, 1-18.

[77] Donaldson K, Poland CA, Schins RP: Possible genotoxic mechanisms of nanoparticles: criteria for improved test strategies. Nanotoxicology 2010, 4, 414-420.

[78] Donaldson K, Duffin R, Langrish JP, Miller MR, Mills NL, Poland CA, Raftis J, Shah A, Shaw CA, Newby DE: Nanoparticles and the cardiovascular system: a critical review. Nanomedicine (Lond) 2013, 8, 403-423.

[79] Estelrich J, Sanchez-Martin MJ, Busquets MA: Nanoparticles in magnetic resonance imaging: from simple to dual contrast agents. Int J Nanomedicine 2015, 10, 1727-1741.

[80] Feng, XL Chen AJ, Zhang YL, Wang JF, Shao LQ, Wei LM: Application of dental nanomaterials: potential toxicity to the central nervous system. Int J Nanomedicine 2015, 10, 3547-3565.

[81] Fernandes E, Ferreira JA, Andreia P, Luis L, Barroso, S, Sarmento B, Santos LL: New trends in guided nanotherapies for digestive cancers: A systematic review. J Control Release 2015, 209, 288-307. 
[82] Franci G, Falanga A, Galdiero S, Palomba L, Rai, M, Morelli G, Galdiero M: Silver nanoparticles as potential antibacterial agents. Molecules 2015, 20, 8856-8874.

[83] Frohlich E: Value of phagocyte function screening for immunotoxicity of nanoparticles in vivo. Int J Nanomedicine 2015, 10, 3761-3778.

[84] Fubini B, Ghiazza M, Fenoglio I: Physico-chemical features of engineered nanoparticles relevant to their toxicity. Nanotoxicology 2010, 4, 347-363.

[85] Gainza G, Villullas S, Pedraz JL, Hernandez RM, Igartua M: Advances in drug delivery systems (DDSs) to release growth factors for wound healing and skin regeneration. Nanomedicine 2015, 11, 1551-1573.

[86] Gendelman HE, Anantharam V, Bronich T, Ghaisas S, Jin H, Kanthasamy AG, Liu X, McMillan J, Mosley RL, Narasimhan B, Mallapragada SK: Nanoneuromedicines for degenerative, inflammatory, and infectious nervous system diseases. Nanomedicine 2015, 11, 751-767.

[87] Gharagozloo M, Majewski S, Foldvari M: Therapeutic applications of nanomedicine in autoimmune diseases: from immunosuppression to tolerance induction. Nanomedicine 2015, 11, 1003-1018.

[88] Gregori M, Masserini M, Mancini S: Nanomedicine for the treatment of Alzheimer's disease. Nanomedicine (Lond) 2015, 10, 1203-1218.

[89] Guo S, Huang L: Nanoparticles containing insoluble drug for cancer therapy. Biotechnol Adv 2014, 32, 778-788.

[90] Gusic N, Ivkovic A, VaFaye J, Vukasovic A, Ivkovic J, Hudetz D, Jankovic S: Nanobiotechnology and bone regeneration: a mini-review. Int Orthop 2014, 38, 1877-1884.

[91] Holden PA, Schimel JP, Godwin HA: Five reasons to use bacteria when assessing manufactured nanomaterial environmental hazards and fates. Current Opinion in Biotechnology 2014, 27, 73-78.

[92] Hristozov DR, Zabeo A, Foran C, Isigonis P, Critto, A, Marcomini A, Linkov I: A weight of evidence approach for hazard screening of engineered nanomaterials. Nanotoxicology 2014, 8, 72-87.

[93] Hubbs AF, Sargent LM, Porte, DW, Sager TM, Chen BT, Frazer DG, Castranova V, Sriram K, Nurkiewicz TR, Reynolds SH, Battelli LA, Schwegler-Berry D, McKinney W, Fluharty KL, Mercer RR: Nanotechnology: toxicologic pathology. Toxicol Pathol 2013, 41, 395-409.

[94] Ilinskaya AN and Dobrovolskaia MA: Nanoparticles and the blood coagulation system. Part II: safety concerns. Nanomedicine (Lond) 2013, 8, 969-981.

[95] Ilinskaya AN and Dobrovolskaia MA: Nanoparticles and the blood coagulation system. Part I: benefits of nanotechnology. Nanomedicine (Lond) 2013, 8, 773-784.

[96] Jo DH, Kim JH, Lee TG, Kim JH: Size, surface charge, and shape determine therapeutic effects of nanoparticles on brain and retinal diseases. Nanomedicine 2015.

[97] Kandi V and Kandi S: Antimicrobial properties of nanomolecules: potential candidates as antibiotics in the era of multi-drug resistance. Epidemiol Health 2015, 37, e2015020.

[98] Kermanizadeh A, Chauche C, Brown DM, Loft S, Moller P: The role of intracellular redox imbalance in nanomaterial induced cellular damage and genotoxicity: a review. Environ Mol Mutagen 2015, 56, 111-124.

[99] Kim YD, Park TE, Singh B, Maharjan S, Choi YJ, Choung PH, Arote RB, Cho CS: Nanoparticle-mediated delivery of siRNA for effective lung cancer therapy. Nanomedicine (Lond) 2015, 10, 1165-1188.

[100] Kodiha M, Wang YM, Hutter E, Maysinger D, Stochaj U: Off to the organelles - killing cancer cells with targeted gold nanoparticles. Theranostics 2015, 5, 357-370.

[101] Lakkakula JR and Macedo Krause RW: A vision for cyclodextrin nanoparticles in drug delivery systems and pharmaceutical applications. Nanomedicine (Lond) 2014, 9, 877-894.

[102] Landriscina A, Rosen J, Friedman AJ: Biodegradable chitosan nanoparticles in drug delivery for infectious disease. Nanomedicine (Lond) 2015, 10, 1609-1619.

[103] Larson JK, Carvan MJ $3^{\text {rd }}$, Hutz RJ: Engineered nanomaterials: an emerging class of novel endocrine disruptors. Biol Reprod 2014, 91, 1-8.

[104] Laurent S, Saei AA, Behzadi S, Panahifar A, Mahmoudi M: Superparamagnetic iron oxide nanoparticles for delivery of therapeutic agents: opportunities and challenges. Expert Opin Drug Deliv 2014, 11, 1449-1470.

[105] Li Y, Dong H, Li Y, Shi D: Graphene-based nanovehicles for photodynamic medical therapy. Int J Nanomedicine 2015, 10, 2451-2459.

[106] Li YF, Zhao J, Qu Y, Gao Y, Guo Z, Liu Z, Zhao Y, Chen C: Synchrotron radiation techniques for nanotoxicology. Nanomedicine 2015, 11, 1531-1549.

[107] Lukowiak MC, Thota BN, Haag R: Dendritic core-shell systems as soft drug delivery nanocarriers. Biotechnol Adv 2015.

[108] Lux F, Sancey L, Bianchi A, Cremillieux Y, Roux S, Tillement O: Gadolinium-based nanoparticles for theranostic MRI-radiosensitization. Nanomedicine (Lond) 2015, 10, 1801-1815.

[109] Madl AK, Liong M, Kovochich M, Finley BL, Paustenbach DJ, Oberdorster G: Toxicology of wear particles of cobalt-chromium alloy metal-on-metal hip implants Part I: Physicochemical properties in patient and simulator studies. Nanomedicine 2015, 11, 1201-1215.

[110] Madl AK, Kovochich M, Liong M, Finley BL, Paustenbach DJ, Oberdorster G: Toxicology of wear particles of cobalt-chromium alloy metal-on-metal hip implants Part II: Importance of physicochemical properties and dose in animal and in vitro studies as a basis for risk assessment. Nanomedicine 2015, 11, 1285-1298.

[111] Mottaghitalab F, Farokhi M, Shokrgozar MA, Atyabi F, Hosseinkhani H: Silk fibroin nanoparticle as a novel drug delivery system. J Control Release 2015, 206, 161-176.

[112] Mulder WJ, Jaffer FA, Fayad ZA, Nahrendorf M: Imaging and nanomedicine in inflammatory atherosclerosis. Sci Transl Med 2014, 6, 239. 
[113] Muller RH, Gohla S, Keck CM: State of the art of nanocrystals - special features, production, nanotoxicology aspects and intracellular delivery. Eur J Pharm Biopharm 2011, 78, 1-9.

[114] Murugan K, Choonara YE, Kumar P, Bijukumar D, du Toit LC, Pillay V: Parameters and characteristics governing cellular internalization and trans-barrier trafficking of nanostructures. Int J Nanomedicine 2015, 10, 2191-2206.

[115] Nel AE: Implementation of alternative test strategies for the safety assessment of engineered nanomaterials. J Intern Med, 2013, 274, 561-577.

[116] Nel A Xia T, Meng H, Wang X, Lin S, Ji Z, Zhang H: Nanomaterial toxicity testing in the 21st century: use of a predictive toxicological approach and high-throughput screening. Acc Chem Res 2013, 46, 607-621.

[117] Nielsen OH: New strategies for treatment of inflammatory bowel disease. Front Med (Lausanne) $2014,1,3$.

[118] Nunez-Anita RE, Acosta-Torres LS, Vilar-Pineda J, Martinez-Espinosa JC, de la Fuente-Hernandez J, Castano VM: Toxicology of antimicrobial nanoparticles for prosthetic devices. Int J Nanomedicine 2014, 9, 3999-4006.

[119] Osmond MJ and McCall MJ: Zinc oxide nanoparticles in modern sunscreens: an analysis of potential exposure and hazard. Nanotoxicology 2010, 4, 15-41.

[120] Panzarini E and Dini L: Nanomaterial-induced autophagy: a new reversal MDR tool in cancer therapy? Mol Pharm 2014, 11, 2527-2538.

[121] Paul A: Nanocomposite hydrogels: an emerging biomimetic platform for myocardial therapy and tissue engineering. Nanomedicine (Lond) 2015, 10, 1371-1374.

[122] Polak P and Shefi O: Nanometric agents in the service of neuroscience: Manipulation of neuronal growth and activity using nanoparticles. Nanomedicine 2015, 11, 1467-1479.

[123] Sadikot RT: The potential role of nano- and micro-technology in the management of critical illnesses. Adv Drug Deliv Rev 2014, 77, 27-31.

[124] Schrofel A, Kratosova G, Safarik I, Safarikova M, Raska I, Shor LM: Applications of biosynthesized metallic nanoparticles - a review. Acta Biomater 2014, 10, 4023-4042.

[125] Sehedic D, Cikankowitz A, Hindre F, Davodeau F, Garcion E: Nanomedicine to overcome radioresistance in glioblastoma stem-like cells and surviving clones. Trends Pharmacol Sci 2015, 36, 236-252.

[126] Shvedova AA, Kagan VE: The role of nanotoxicology in realizing the 'helping without harm' paradigm of nanomedicine: lessons from studies of pulmonary effects of single-walled carbon nanotubes. J Intern Med 2010, 267, $106-118$.

[127] Sosnik A, Carcaboso AM: Nanomedicines in the future of pediatric therapy. Adv Drug Deliv Rev 2014, 73, $140-161$.

[128] Sriraman SK, Aryasomayajula B, Torchilin VP: Barriers to drug delivery in solid tumors. Tissue Barriers 2014, 2, e29528.

[129] Tan A, Yildirimer L, Rajadas J, De La Pena H, Pastorin G, Seifalian A: Quantum dots and carbon nanotubes in oncology: a review on emerging theranostic applications in nanomedicine. Nanomedicine (Lond) 2011, 6, $1101-1114$.

[130] Torchilin VP: Multifunctional, stimuli-sensitive nanoparticulate systems for drug delivery. Nat Rev Drug Discov 2014, 13, 813-827.

[131] Tseng YY and Liu SJ: Nanofibers used for the delivery of analgesics. Nanomedicine (Lond) 2015, 10, 1785-1800.

[132] Veiseh O, Tang BC, Whitehead KA, Anderson DG, Langer R: Managing diabetes with nanomedicine: challenges and opportunities Nat Rev Drug Discov 2015, 14, 45-57.

[133] Vellayappan MV, Balaji A, Subramanian AP, John AA, Jaganathan SK, Murugesan S, Supriyanto E, Yusof M: Multifaceted prospects of nanocomposites for cardiovascular grafts and stents. Int J Nanomedicine 2015, 10, 2785-2803.

[134] Vinogradov S, Warren G, Wei X: Macrophages associated with tumors as potential targets and therapeutic intermediates. Nanomedicine (Lond) 2014, 9, 695-707.

[135] Walmsley GG, McArdle A, Tevlin R, Momeni A, Atashroo D, Hu MS, Feroze AH, Wong VW, Lorenz PH, Longaker MT, Wan DC: Nanotechnology in bone tissue engineering. Nanomedicine 2015, 11, 1253-1263.

[136] Wang J, Wu W, Jiang X: Nanoscaled boron-containing delivery systems and therapeutic agents for cancer treatment. Nanomedicine (Lond) 2015, 10, 1149-1163.

[137] Weissig V, Guzman-Villanueva D: Nanopharmaceuticals (part 2): products in the pipeline. Int J Nanomedicine 2015, 10, 1245-1257.

[138] White-Schenk D, Shi R, Leary JF: Nanomedicine strategies for treatment of secondary spinal cord injury. Int J Nanomedicine 2015, 10, 923-938.

[139] Winkler DA, Mombelli E, Pietroiusti A, Tran L, Worth A, Fadeel B, McCal, MJ: Applying quantitative structure-activity relationship approaches to nanotoxicology: current status and future potential. Toxicology 2013, $313,15-23$.

[140] Zhao H, Li Y, Hu Y: Nanotechnologies in glycoproteomics. Clin Proteomics 2014, 11, 21.

[141] Zhen Z, Tang W, Todd T, Xie J: Ferritins as nanoplatforms for imaging and drug delivery. Expert Opin Drug Deliv 2014, 11, 1913-1922.

[142] Wang J, O’Sullivan, S, Harmon S, Keaveny R, Radomski MW, Medina C, Gilmer JF: Design of barbituratenitrate hybrids that inhibit MMP-9 activity and secretion. J Med Chem 2012, 55, 2154-2162.

[143] Chung A, Wildhirt SM, Wang S, Koshal A, Radomsk, MW: Combined administration of nitric oxide gas and iloprost during cardiopulmonary bypass reduces platelet dysfunction: a pilot clinical study. J Thorac Cardiovasc Surg 2005, 129, 782-790. 
[144] Saito M, Gunji Y, Kashii Y, Odaka J, Yamauchi T, Kanai N, Momoi MY: Refractory kaposiform hemangioendothelioma that expressed vascular endothelial growth factor receptor (VEGFR)-2 and VEGFR-3: a case report. J Pediatr Hematol Oncol 2009, 31, 194-197.

\section{Address for correspondence:}

Marek W. Radomski

School of Pharmacy and Pharmaceutical Sciences

The University of Dublin

Trinity College

Dublin

Ireland

Tel: +35 318962819

E-mail: marek.radomski@tcd.ie

Conflict of interest: None declared

Received: 17.10.2015

Revised: 10.11 .2015

Accepted: 4.12.2015 